Tourism Research Journal

E-ISSN: 2598-9839

2018, Vol. 2 No. 1

\title{
Benefits of Participation in Student Organization in Tourism Education: Professional and Working Opportunities Through Experience
}

\author{
Lestari Nigrum ${ }^{1 *}$, Monica Azalia ${ }^{2}$ \\ 1,2 Trisakti School of Tourism \\ *lestarinigrum@stptrisakti.ac.id
}

\begin{abstract}
Extracurricular organizations are beneficial to college students. They help in bringing students and institutions together, let students interact in a non-formal atmosphere, and allow students to strengthen their leadership and communication skills. There are at least what books, articles, and advisors will tell the students. In today's society, employers are hiring students more on what they can do, not their grade point average. Participating in extracurricular organizations shows future employers that students can handle school, work, and other activities, which in turn shows responsibility and organization. Do students really understand this?. Sometimes labeled as "the other education", participation in extracurricular activities provides opportunities for students to apply classroom knowledge to real world settings and develops skill that will assist in the practical realities of living after graduation. This research uses qualitative phenomenological, which aims to describe the activities of students during the process of becoming members of student organizations on campus, and to share her experiences and the benefits of the activities of the organization that she attended over the years. Using a sample of one student. The results of this study show that by holding several important positions in student organizations on campus and playing an active role, it is very useful, because their performance professional and ending with gaining experience teaching children of primary school, and became a student independent, self-confident and has experience in the organization before she underwent training in the industry and work upon graduating from college in 2018.
\end{abstract}

Keywords: Tourism education, Student organization, Organization experience

Tourism Research Journal, Volume 2 (1), 2018 
Benefits of Participation in Student Organization in Tourism Education: Professional and Working Opportunities Through Experience

\section{A. Introduction}

In addition to being individual beings, humans are also created as social creatures, where humans cannot live without the help of other human beings. For that reason, there is a term of cooperation, where it is done because of the mutual need factor between one another. In the system of cooperation, can be done by two people, and each of them must have advantages and disadvantages. So, expected with the cooperation of one and another members can complement each other, ultimately the original goal to be achieved can be realized easily. Each member of the group of coworkers holds their respective roles and functions, thereby clearly showing how the structure of the cooperation will ultimately lead to the establishment of the organization.

In general, people in Indonesia still consider that one of the requirements to get a job that 'good' and decent, it must follow and graduate college. Then maybe it is no longer valid in this era. A time of all irony, an age that never gives more hope than what is expected.

Formal education is not always directly proportional to prosperity. Some of the millionaires who are on the Forbes magazine's richest man list have never graduated from college. Of the 400 people included in the Forbes 400 richest list of magazines, 63 entrepreneurs or $15 \%$ of whom never graduated from college. (source: Lintasberita.com). Unlike foreign education, First-year college students are often thrust into self-directed learning experiences that require them to more effectively lead themselves, even though much of their formal learning to that point has been teacher directed in nature (Moebius-Clune,et al, Elsevier, 2011; Dembo \& Seli, 2013; Eckton, 2017)

Especially if the lecture has been associated with work experience, the accretion of unemployment bachelor is not a strange thing anymore. Currently, most companies that provide job vacancy always put a working experience requirement for at least 1-2 years. So the problem is not because there are no job vacancies, but because the number of jobs that are not suitable for a scholar when it is the gate to gain work experience although initially not in accordance with what we expect.

In today's society, employers are hiring students more on what they can do, not their grade point average. Participating in extracurricular organizations shows future employers that students can handle school, work, and other activities, which in turn shows responsibility and organization. Do students really understand this? (Hegedus and James Knight, 2002). One way to gain experience while undergoing the lecture process and to gain experience is to become a member of a campus organization. Law number 12 of 2012 on Higher Education, has regulated and authorized to regulate the formation of student organizations on campus. The Internal-Campus Student Organization is a student organization attached to a private campus or university, and has an official status in a college setting. The organization is funds for independent student activities, from college managers and/or from Ministries/Agencies, Government and non-government to advance work programs and other advancements. The form can be Student Association, such as Student Executive Board (SEB, In

Tourism Research Journal, Volume 2 (1), 2018 
Benefits of Participation in Student Organization in Tourism Education: Professional and Working Opportunities Through Experience

Indonesia called : BEM), Student Senate level faculty and Student Association Majors (SAM, In Indonesia called : HMJ).

Extracurricular organizations are beneficial to college students. They help in bringing students and institutions together, let students interact in a non-formal atmosphere, and allow students to strengthen their leadership and communication skills. There are at least what books, articles, and advisors will tell the students.

(1) Can achieve the expected goals together more efficiently

The objectives that have been set together will be achieved jointly / collaboratively with the responsibilities that have been prepared for each member of the organization.

(2) Problems can be solved easily

Trained to decide the problem together, in the life of the organization, problems arising not only charged or decided by one member only, but all members must participate actively in solving the problems that arise so as not to have an impact due to social conflict that occurred in community. Thus, the members will be trained on how to behave and address every problem that arises in the life of the community.

(3) The emergence of a spirit of cooperation

Every member of the organization is required to participate in any matters relating to the organization. And in any case related to the crowd certainly cannot be charged, only to one person, but required cooperation from other members. Thus, each member will be encouraged to work with each other so that the goal they want to achieve can be realized.

(4) Developing Public Speaking Skills

Have the ability and courage to speak in public is not easy, it takes a long time to train so oneself can have that ability. Organization is an appropriate means for someone to be able to train and develop the ability and courage someone related to public speaking, such as conveying opinions, speech, and so forth

(5) Train the Leadership Soul

Organization is a place where the soul of leadership in us can be honed, namely by prioritizing the public interest rather than personal interests. In addition, in an organization one is taught how to make wise decisions by not harming any party.

(6) Could train someone to interact with different characters

An organization certainly consists of more than one person, in which one person and another have different characteristics and characteristics. This will help train someone to interact with others without discriminating one another.

(7) Broaden one's insight and knowledge

Activities, seminars, workshops, training, and other activities are one agenda that exists within an organization as the impact of globalization.

(8) Can expand one's association

In an organization there are linkages between members who one with other members. This is as a result of the interaction and cooperation that takes place between members of the organization. Thus the relationship of friendship will become more widespread.

(9) Can show one's identity and personality

Tourism Research Journal, Volume 2 (1), 2018 
Benefits of Participation in Student Organization in Tourism Education: Professional and Working Opportunities Through Experience

In general, someone who is active in organizing, especially for teenagers will be able to find their identity and personality, that is, from the environment and the association of the community or organization that they form.

\section{Can form Emotional Intelligence Quotient (EQ)}

In addition to personality, the existence of the environment within the organization that is formed will be able to influence the development of one's emotions, where a good environment will be able to create a good emotional state as well. With a good EQ, then someone will be able to mix and deal with people with a different type of personalities.

(11) Can help someone to be able to divide his time and be more responsible It is very important for us to make the most of our time. Organizations are the right choice for us to learn to value time and organize every schedule of our activities. A person who is active in the organization will be able to cultivate a sense of responsibility within him/her self.

(12) Can foster discipline and work ethic for a person and one's selfconfidence

By organization, will be able to have the ability to convey ideas, negotiate well, have the ability to change things for the better.

\section{Can train someone to be stronger in the face of pressure}

In organizations, a person is trained to be able to convey ideas, be given the confidence to perform certain tasks.

It is linear with the opinion of Hegedus \& Knight, 2002 which states that "Extracurricular organizations are beneficial to college students. They help bring students and faculty together, let students interact in a non-formal atmosphere, and allow students to strengthen their leadership and communication skills". Research suggests that through higher education will make students as leaders (Stogdill, 1959; Jacobson.,et all., 1973: Dembo \& Seli, 2013), other research suggests that education attainment is a key indicator of individual leadership ability (Birkenholz, et al., 1993) also there are attributes leaders can seek to attain that will enable themto lead more positively and effectively. Leaders, or future leaders, should consider storytelling, emotional intelligence, and organizational commitment as attributes that will assist in more successful and effective leadership (Montague, 2017). Again, these statements cover what makes leaders, not what drives students to participate in organizations, a high factor for the college experience. Some undergraduate students may enter the stage of relativism where they actively construct knowledge and meaning from information and their own experiences (Fosmire, 2013 in Eckton, et al.,2017), similar to active learning, and in the process become more self-directed (Bembenutty, 2011; Eckton, et al., 2017)

\section{B. Literature Review}

\section{High Education}

Education in Indonesia is a major supplement in a changing world filled with technological developments. According to Nelson Mandela, "education is the most lethal weapons in the world because we can change the world with it" (Ningrum.,

Tourism Research Journal, Volume 2 (1), 2018 
Benefits of Participation in Student Organization in Tourism Education: Professional and Working Opportunities Through Experience

et.al.,2017). Higher Education has several functions, and as it is stated in Law No. 12/2012 Article 4, higher education has three (3) function as follows: 1). Develop ability and character development and as well as dignified civilization in the context of the intellectual life of the nation. 2). Develop innovative, responsive, creative, skilled, competitive, and cooperative academic community through the implementation of three responsibilities. 3). Develop Science and Technology by considering and applying the value of the humanities. In addition, of having function, higher education also has several goals.

\section{Organization}

Organization is a group of people in means for a common purpose. In the social sciences, organizations are studied by researchers from various fields of science, especially sociology, economics, political science, psychology, and management. Organizational studies are often called organizational studies, organizational behavior, or organizational analysis (Davis, et. al., 2005).

The organization has basically used as a place or place for people to gather, cooperate rationally and systematically, planned, guided and controlled, in utilizing resources (money, materials, machinery, methods, environment), tools, data, And so on that are used efficiently and effectively to achieve organizational goals.

An organization can be formed because it is influenced by several aspects such as the unification of vision and mission and the same goal with the realization of the existence of a group of people to the community. A well-regarded organization is an organization that can be acknowledged by its surrounding community, because it contributes to; The taking of human resources in society as its members thereby reducing the unemployment rate. This likeness does not mean lifelong membership On the contrary, organizations face constant change in their membership, even when they become members, people in organizations participate relatively regularly (Davis et.al., 2005).

As society changes, so must its institutions. Despite decades of structural barriers that impeded the educational achievement of many students of color (Darder, 1991; Feagin, 2002; Rendon,et al., 2000; Maramba, 2012). As society changes, so must its institutions. Despite decades of structural barriers that impeded the educational achievement of many students of color most colleges and universities have become more ethnically diverse (Rendon,et al., 2000; Maramba, 2012).

Although the trends differ across many states, regions, and types of institutions, the increasing diversity of post secondary students has many critical implications for policy. Students from varying cultures, socioeconomic backgrounds, and immigration profiles raise critical questions about how today's college students are taught, what they are taught, and who teaches them. Students from varying cultures, socioeconomic backgrounds, and immigration profiles raise critical questions about how today's college students are taught, what they are taught, and who teaches them (Wlodkowski \& Ginsberg, 1995; Maramba., 2012). Trisakti School of Tourism Jakarta is also a school with a diverse student's background, socioeconomic, although not yet fully diverse in different countries. Maluku-Ambon and Papua, even students from the Middle East (Iran) and Korea ever attended lectures in Trisakti School of Tourism Jakarta Indonesia. With the diversity in communicating and running the learning process,

Tourism Research Journal, Volume 2 (1), 2018 
Benefits of Participation in Student Organization in Tourism Education: Professional and Working Opportunities Through Experience

students of the Trisakti School of Tourism, have experience in overcoming the culture shock within the campus.

Robbins (2007) states that Organizations are consciously consciously coordinated social entities, with a relatively identifiable constraint, working on a relatively continuous basis for a common goal or a set of goals. Kusdi, 2009 and Pratiwi, 2016), defines the organization as follows: "A continuing system of differentiated and coordinated human activities utilizing, transforming, and welding together a specific set of human, material, capital, ideational, and natural resources into a unique problem-solving whole engaged in satisfying particular human needs in interaction with other systems of human activities and resources in its environment."

\subsection{Work ethics in organization}

In organizing there will certainly be some who are inactive and some are more active than others. It is naturally because of background differences and some person or group issues. The work ethics is an idea that emphasizes individualism or the independence and positive influence of work on the individual. The work is considered good because it can improve the degree of life and social status of a person. Working hard will ensure the success (Umam, 2012).

\subsection{Student}

The student is a person who is in the process of studying or studying and enrolled is undergoing education in one form of college consisting of academic, polytechnic, high school, institute and university Hartaji, 2012 and Pratiwi, 2016. Student can be defined as individuals who are studying at the college level, both public and private or other institutions at the same level with college Siswoyo, 2007 and Pratiwi. 2016.

\subsection{Organizing Scholar}

Sometimes labeled as "the other education", participation in extracurricular activities provides opportunities for students to apply classroom knowledge to real world settings and develops skill that will assist in the practical realities of living after graduation (Astin, 1993; Kuh, 1995; Montelongo, 2002). Based on research conducted by Marantika (2007) and Pratiwi (2016), obtain results that activity of student extracurricular organization has a negative effect to student achievement, whereas learning, motivation have a positive influence to student achievement. In this case it can be analyzed that students who actively participate in extracurricular field is not / have not been able to manage time between organizational activities with the main task of students as students. However, on the results of research on different campuses conducted by Rofiq(2013) produces data that shows that there is a positive and significant influence between organizational activities on student achievement. The added supplement of extracurricular activity involving a student's college experience. (Astin, 1993; Craig \& Warner, 1991; Montelongo, 2002)

\section{Research Methodology}

Qualitative research was selected for this study with a phenomenological approach. According to Strauss and Corbin in Mamik (2015) qualitative research is a

Tourism Research Journal, Volume 2 (1), 2018 
type of research that results in unachievable findings by using statistical procedures or other means of quantification (measurement). Qualitative research in general can be used for research on community life, history, behavior, organizational functionalization, social activities, and others. A qualitative approach is expected to produce in-depth descriptions of the words, writings, and / or behavior that can be observed from a specific individual, group, society, or organization in a particular context setting studied from a holistic, comprehensive, and holistic viewpoint. Phenomenology is a method of analysis trying to understand reality as it is in its purity. Phenomenological research tries to explain or reveal the meaning of the concept or phenomenon of experience based on awareness that occurs in some individuals.

The researcher in this case develops the meaning of the individual and also asks the individual to describe the experience of daily life. The subject of observation is a student named Monica.

The Phenomenological Approach can be classified in purely qualitative research were in its practice it is based on the study of and describes the intrinsic characteristics of the phenomena as the phenomena themselves. The researcher must depart from the subject (human) as well as his consciousness and seek to return to "pure consciousness" by freeing himself from the experiences and images of everyday life in the conduct of research. Therefore, this study does not use sampling techniques, either in the form of interviews or questionnaires, so there is no instrument available. The discussion in this study comes from the personal experience of the subject / unit of analysis of this study.

Data collection and processing are generally observational. Describe how the data was analyzed in the study.

\section{Result}

On most campuses, college student organizations tend to fall into the following categories: governing bodies, social organizations, student government groups, academic clubs, religious organizations, and special interest/cultural groups (Astin, 1993; Craig \& Warner, 1991; Montelongo, 2002).

Student Organization at Trisakti School of Tourism Jakarta is an organization that serves to accommodate student activities and become a means for students to learn to organize. Student organization consists of Student Congress, Student Presidency, and 19 Student Activity Unit, which is directly supervised by Field 3 Student Affairs of Trisakti School of Tourism.

The function of the Student Congress as the highest student organization is to oversee and evaluate the course of campus activities and situations, and also serves as a forum for students to channel their aspirations about the campus. During the first semester, she became a committee in the Election Commission. The General Election Commission is one of the work programs of the Student Congress, which aims to elect the student president of the next period.

At that time of joining the licensing division committee gets the task to create a permit, administer the administration, and set everything that requires permission to be used. Joining in this activity is a very rewarding experience because this activity is a formal activity.

All things must be done by asking permission, then everything done must be properly recorded and true, and the entire student community must know the process

Tourism Research Journal, Volume 2 (1), 2018 
of the presidential election from beginning to end without any indication of fraud, same like the presidential election in Indonesia. By joining in this activity as well, students in the organization train themselves to be honest, diligent, quick and professional person.

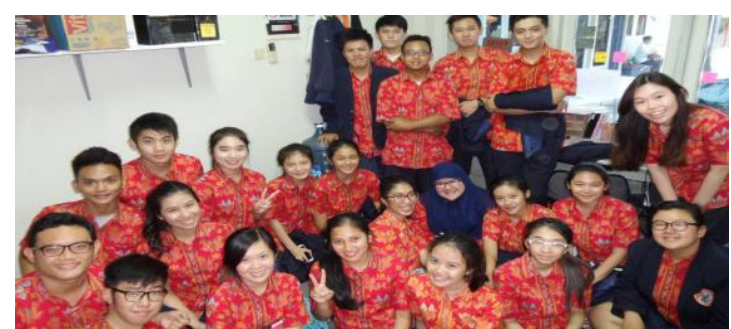

Source: Private 2017

Figure 1. The Election Commission Committee

Subsequent to the activities of the General Elections Commission, which is the work program after the members of the Student Congress is over, in the next semester the student who has been assessed has had the achievement in the previous membership was recruited as treasurer of the Student Congress. As treasurer, get the opportunity to join the Student Congress due to the experience that has been joined in the work program of Student Congress, so the decision to appoint students with certain positions viewed from the achievements in the organization.

In the activities of the Student Congress, the experience gained is widespread and numerous. The Student Congress is a wider scope of organization. As the highest organization on campus, we supervise, control and evaluate every activity that takes place on campus. Congress also discusses the rules that must be made for the interests of students and campuses, such as the enforcement of smoking rules on campus, etc. In addition, Congress also oversees the student community, if they have any aspirations, they submit it to Congress, then the Student Congress will review and submit it to campus management.

The Congress also has work programs, among them leaders of Working Meetings, namely meetings aimed at distributing funds for student activities for Student Activity Unit, carrying out the General Election Commission which aims to elect the president of the next period of student, and then the Leadership Management Training Course which is devoted to the Management - Student Organization board. This activity contains seminars, exercises to become leaders, as well as activities - activities that are intended to bring out the leader, honesty, reliable, professional, and others in the board of Student Organizations. Becoming a Student Congress is not an easy thing. Our self is always seen by the student community, so as a role model, we should be kind, fair, wise, and always exemplify the right thing. 
Benefits of Participation in Student Organization in Tourism Education: Professional and Working Opportunities Through Experience

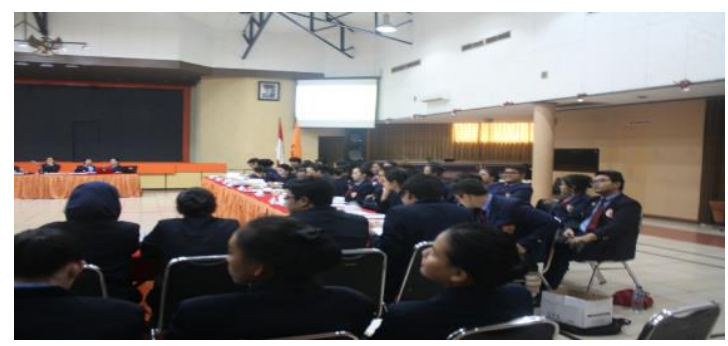

Sumber : Private 2017

Figure 1. Meeting Responsibility Report Activity

In addition, members of Congress often meet to discuss what happened on campus, why it can happen, and future solutions. Then, also have to review the existing rules on the campus, whether still effective or should be changed, if want to be changed like what, whether it is useful for students, and there are many other things that must be considered and negotiated. However, Congressional struggle is proportional to what it achieves. Activities in Congress make all members a better person.

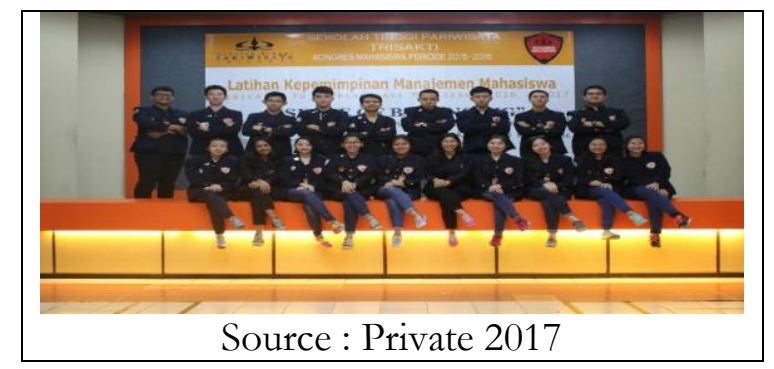

Figure 3. The Photo of Commitee After Undergoing Leadership Training

If in the previous stewards, members of the organization work well, it is likely in the next semester will be trusted to hold a position in the organization. For example, it is believed to be the Daily Board of the Badminton Student Unit Candidate. In this badminton activity more activities to play and exercise, so this activity is very fun. But in addition to exercise, also has another work program that is Training Camp and Charity. Training Camp is an event to familiarize themselves with each other, as well as physical exercise that aims to strengthen the physical that is very influential on the ability to play badminton.

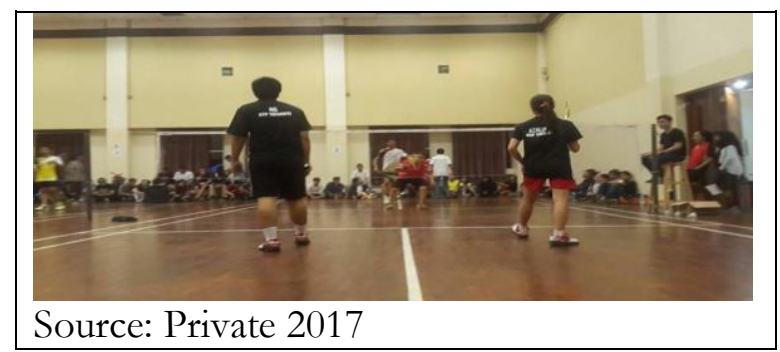

Figure 4. Badminton Competition at Nusantara Institute of Bussiness Jakarta Indonesia

Tourism Research Journal, Volume 2 (1), 2018 
Benefits of Participation in Student Organization in Tourism Education: Professional and Working Opportunities Through Experience

As for Charity itself, it is a visit to the orphanage and performs with the children of the orphanage, members of the organization play together, sing together and also the provision of food and money to the orphanage. This charity was held in October 2016, exactly on the 22nd, at Panti Griya Yatim Dhuafa, Tanah Kusir - Jakarta Indonesia. Charity is selected close to the campus, with the aim that students can share and learn to empathize with the community around their own environment. The committees of each member must end when entering the 6th semester of the semester for an internship. Though out of the Badminton committee, several former members of the organization remain mentors to control the running of the new Executive Board $(\mathrm{BPH})$ of the new period.

One of the benefits of organizing that truly benefit directly to life and of course will be the experience of stock after graduating from college to work, is to be a lecturer at MI Al-Jihaddiyah Bintaro Jakarta. An excellent opportunity to teach children who attend elementary school. This opportunity is based on the TOEIC test result (745), where the Trisakti School of Tourism through KKMK English sets the standard "excellent" / that exceeds the standard (500), so students can choose whether they want to be teachers, or want to take children The trip to Taman Mini, and some other options. Because she want to try new experiences, and finally chose to be a teacher, where teaching children is more difficult because the way of teaching also must be liked and easily understood by the elementary school level children, if the way of teaching is not appropriate of course the child will not be interested by us.

Being a teacher for about 3 weeks, forming a responsible person because every night before bed, must prepare materials that will be distributed to the children the next day, of course, through the process of thinking, consideration, analysis of what the material will be given as well as thinking how to deliver the material and so forth. After doing the teaching process will certainly evaluate whether the material is appropriate and useful for children. One of the strategies in providing classroom teaching is prepared gifts for the games. Teaching children is not easy, they often run around, do not listen, bored, and many other things that make it difficult to be a teacher and also feel very grateful for the struggle of teachers who struggle to provide knowledge for their students. The completion, of being a teacher is covered with photos together with children, as well as gift sharing with them.

This experience is a very valuable experience for students who have the opportunity to become teachers. On the whole, participation in college student organizations appear to provide students with a variety of opportunities to become better acquired by the campus life within an institution.

Tourism Research Journal, Volume 2 (1), 2018 
Benefits of Participation in Student Organization in Tourism Education: Professional and Working Opportunities Through Experience

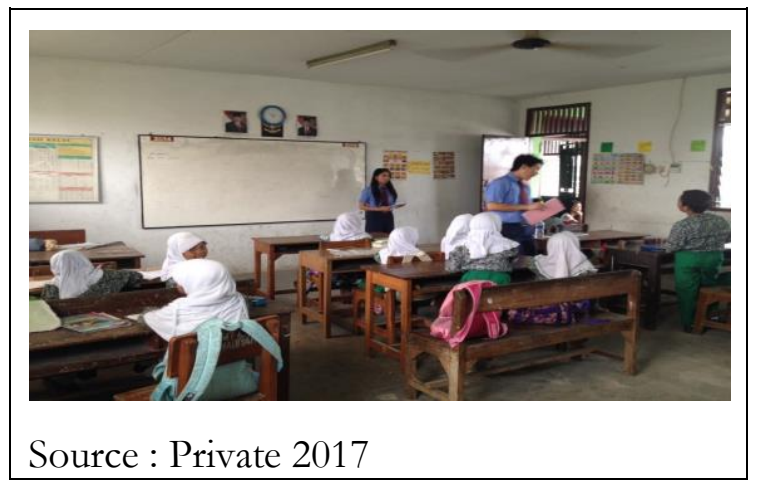

Figure 5. Teaching the Elementary Students

\section{E. Discussion}

Her experience in participating in extracurricular activities that organizes strengthens the results of Astin (1993), Kuh (1995), Montelongo (2002), and Rofiq (2013). Her success in arranging time between studying and beroganisasi broke the research results of Marantika (2007) and Pratiwi (2016). Monica is one of her outstanding students.

In education known as Tridharma education, which is the obligation of universities to hold education, research, and community service (article 1 (9) of Law 12 Year 2012. Where, the three activities not only involve lecturers as teachers, also must involve college student.

Research is an activity conducted according to scientific principles and methods systematically to obtain information, data, and information relating to the understanding and / or testing of the science, technology branch, for students not only when they make the thesis, but it is expected that they are able to write the paper, scientific articles and national or international journals, certainly with his lecturer's guidance. Is Science Student Gained During Education In Higher Education Only Saved Only? As a Smart Man, Students are Expected Able to Implement Scientific Division That Is Through Its Through Research.

The Second Tridharma Element is Very Important. Higher Education Without Presence Research Will Be Considered as Unproductive And Underdeveloped Universities. For most tourism students whose education is applied, it is not an easy thing to write scientifically, but because it is a requirement for universities to be able to activate their students in scientific research activities, the Government of Indonesia has set a rating for universities (best) through 4 elements of assessment, i.e. human resources, student activities, research and publications and accreditation. The word "publication" in the research emphasizes that the resulting manuscript results are required to be published widely in order to be read and useful to others, whether by application, motivation or for an anticipation and solution.

This paper was created, one of which is to train students to make scientific manuscripts from their own sources of experience, hoping to motivate other students to do the same. 
Benefits of Participation in Student Organization in Tourism Education: Professional and Working Opportunities Through Experience

\section{F. Conclusion}

A variety of student development changes in regards to cognitive and affective growth are associated with participation in college extracurricular activities. Extracurricular activity involvement cultivates noticeable changes in a student's behavioral traits and personality characteristics. In college life, it is not enough to just come to class and go home. Campus life needs to be filled with a variety of activities that will be useful in the future.

By learning about how to organize, personal students will be trained to become a better person. Both in terms of attitude, experience, and many other things that develop. Although students have to sacrifice in a lot of things for the organization, must be willing to spend time for meetings till night, have to think of many things other than lectures, have to do many things for the organization, and many more, but the results are worth it and can automatically apply time management effectiveness. If humans do not go through many difficulties, of course the person concerned will not develop. Precisely because there are difficulties and problems, the person concerned will be trained to be able to solve the problem. Precisely because there are difficulties and problems, the person concerned will be trained to be able to solve the problem. On the basis of that, students will not feel sorry to have followed many organizations and sacrificed for the sake of the organization, because they will be satisfied with the results and achievements.

Therefore, do not be afraid to organize, because students will get a very valuable experience and the various benefits that will be very useful for life in the future, and college campus environments with multiple student life components provide opportunities for organizations participation that could influence subsequent participation in such activities.

\section{G. Acknowledgement}

Thanks to Monica, who has been willing to cooperate in making this manuscript, hopefully, experience in organizing and experience of passing up the experience of writing can be transmitted to other students.

\section{REFERENCES}

Astin, A.W. (1993). What Matters in College? Four-critical years revisited. San Fransisco:Jossey-Bass

Birkenholz, R., McKinley, and Stewart (1993). Characteristics and Experiences Related to the Leadership Skills of Agriculture Students in College. Columbia:University of Missouri.

Bembenutty, H. (2011). Introduction of learning in post secondary education. New Directions for Teaching and Learning, 125, 3-8.

Craig, D.H. \& Warner, T.R. (1991). Working together: The "forgotten Majority" of student organizations and campus activities. Campus Activities Programming, 23(9),42-46.

Davis, G.F., and Christopher.M.(2005). "Prospects for organization theory in the early 21st century: Institutional fields and mechanisms," Organization Science 16:32-43.

Darder,A. (1992). Culture and Power in the Clasrrom: A critical foundation for bicultural education. New York, NY : Bergin \& Garvey.

Tourism Research Journal, Volume 2 (1), 2018 
Benefits of Participation in Student Organization in Tourism Education: Professional and Working Opportunities Through Experience

Dembo, M. H., \& Seli, H. (2013). Motivation and learning strategies for college success: A focus on self-regulated learning. New York, NY: Routledge.

Eckton, D.R and S. Rheet.P.(2017). Self-Directed Learning as a Form of SelfLeadership:An Exploratory Study in a first-year experience student success course. The Journal of Student Leadership. Volume 1 Issue 2 - 2017.p.15-29.

Feagin, J. (2002). The continuing significance of racism: US collages and universities. Washington, DC: American Council on Edication.

Fosmire, M. (2013). Cognitive development and reflective judgment In information literacy. Issues in Science and Technology Librarianship, Fall 2013. doi:10.5062/F4X63JWZ .

Hagedus. C.M dan James.K. (2002). Student Participation in Collegiate Organizations Expanding the Boundaries. University of Arizona http://www.leadershipeducators.org/Resources/Documents/Conferences, downloaded on 25 Maret 2017.

Indonesia. Undang-Undang Nomor 12 Tahun 2012 Tentang Perguruan Tinggi.

Jacobson, P.B., Logsdon, J.D., and Wiegman, R.R. (1973). The Principalship:New Perspectives. New Jersey: Prentice-Hall Inc.

Kuh, G.D. (1995). Other Curriculum. Out-of-Class Experiences Associated with Student Learning and Personal Development. Journal of Higher Education. Vol. 66, No. 2 (March/April 1995). Copyright 1995 by the Ohio State University Press.

Kusdi. (2009). Teori Organisasi dan Administrasi. Jakarta : Salemba Humanika.

Khaerul.U. (2012). Perilaku Organisasi. Bandung : Pustaka Setia.

Mamik. (2015). Metode Kualitatif. Sidoarjo : Zifatama Publishing. ISBN : 978-602-166265-6.

Marantika.I.(2007).Pengaruh Keaktifan Organisasi Ekstrakulikuler dan Motivasi Belajar terhadap Prestasi Belajar Mahasiswa FE Universitas Negeri Malang. (Unpublished Skripsi). Universitas Negeri, Yogyakarta

Maramda, D.C. And Partick. V. (2012). Influences Experience on the Ethnic Identity Development of Student of Color. Sage.Sagepub.com/journalspermmisions.nov.educations and urban society.44(3)294-317.

Rofiq. M. N. (2013). Pengaruh Aktrifitas Berorganisasi terhadap Indeks Prestasi Belajar Mahasiswa Jurusan KSDP Fakultas Ilmu Pendidikan Universitas Negeri Malang. (Unpublished Skripsi). Universitas Negeri, Malang.

Moebius-Clune, B., Elsevier, I., Crawford, B., Trautmann, N., Schindelbeck, R., \& van Es. (2011). Moving authentic soil research into high school class-rooms: Student vengagement and learning. Journal of Natural Resources \& Life Sciences Education, 40 (1), 102-113.

Montague, Amanda,2012. Attributes that Build Effective Leaders. The Journal of Student Leadership. Volume 1 Issue 2. 2017. P 59-65.

Montelongo, R. (2002). Student Paticipation in College Student Organizations: A Review of Literature. Journal of the Indiana University Student Personnel Association. 5063

Ningrum. Lestari, Sri S, Fachrul.H.H. (2017). The Socialization Of ISO 9001 and SOP Implementation Learning Process By Using Kirkpatrick's Model For Students' Tourism. IOSR Journal Of Humanities And Social Science. ISSN: 2279-0837, p-ISSN:

Tourism Research Journal, Volume 2 (1), 2018 
Benefits of Participation in Student Organization in Tourism Education: Professional and Working Opportunities Through Experience

2279-0845. www.iosrjournals.org/Volume 22, Issue 10, Ver. I (October. 2017) PP 31-43. doi: 10.9790/0837-2210013143

Pratiwi. S.S. (2016). Pengaruh Keaktifan Mahasiswa dalam Organisasi dan Motivasi Belajar terhadap Prestasi Belajar Mahasiswa Fakultas Ekonomi Universitas Negeri Yogyakarta. (Unpublished Skripsi). Universitas Negeri, Yogyakarta.

Robbins, Stephen P. (2007), Perilaku Organisasi : Konsep, Kontroversi,Aplikasi; Jilid 1 dan Jilid II, Edisi Kedelapan, Alih Bahasa: Hadyana Pujaatmaka dan Benyamin Molan, Jakarta: PT. Prenhallindo

Rendom,L. Jalomo. R \& Nora, A. (2000). Theoretical consideratuions in the study of minority student retention in higuber education. In J. Braxton (Ed.), Reworking student departure puzzle. Nashville, TN:Vanderbilt University Press.

Siska Sinta Pratiwi. (2016). Pengaruh Keaktifan Mahasiswa dalam Organisasi dan Motivasi Belajar terbadap Prestasi Belajar Mahasiswa Fakultas Ekonomi Universitas Negeri Yogyakarta. (Unpublished Skripsi). Universitas Negeri, Yogyakarta.

Stogdill, R.M. (1959). Individual behavior and group achievement. New York : Oxford University Press.

Wlodkowski,R., \& Ginsberg, M. (1995). Diversity and Motivation: Culturally responsive teaching. San Fransisco: CA:Jossey-Bass.

Tourism Research Journal, Volume 2 (1), 2018 